\title{
SOME OBSERVATIONS ON THE TRANSITION ZONE BETWEEN THE XEROSERE AND THE HALOSERE ON THE BOSCHPLAAT (TERSGHELLING, THE NETHERLANDS) WITH SPECIAL ATTENTION TO CENTAURIUM VULGARE RAFN
}

\author{
A. H. J. FREIJSEN \\ (Biological Station 'Weevers' Duin', Oostvoorne, the Netherlands) \\ (received October 12th, 1965)
}

\begin{abstract}
Three important plant communities were studied on the salt marsh "the B sschplaat" on the Westfriesian island of Terschelling: the Centaurieto-Saginetum moniliformis -D., S. et W. 1940, the Sagineto maritimae-Cochlearietum danicae Tx. et G. 1957 and the funcetum gerardii W. 1906 (Table 1). The boundary lines of these associations are determined by soil moisture, salinity and density of vegetation.

Five bare field plots were prepared in the transition zone. 'The establishment of species was followed during one year. For most species the original pattern was rapidly restored with some exceptions e.g. Centaurium vulgare Rafn (Table 3). Lifecycle and distribution pattern of Centaurium vulgare were more exactly investigated on one field plot (Table 4). Competition, density of adult plants, density of seedlings and soil moisture appeared to de dependent on each other in this sequence.
\end{abstract}

\section{The LOCALITY}

The underlying survey was performed on the salt marsh 'the Boschplaat', which forms the eastern point of the Westfriesian island of Terschelling. This salt marsh is periodically inundated from the south. On the northern side of the Boschplaat a sand dike stretches from west to east. On the south coast there occur four dune-groups: Eerste, Tweede, Derde and Vierde Duintjes ('First, Second, Third and Fourth Little Dunes'). These four dune-groups are separated by tidal channels. Through these channels the water of the WaddenSea inundates the salt marsh. The 'Duintjes' are only partly inundated by storm-floods.

Between sand dike and dune-groups there occur numerous very small dunes on the salt marsh. These almost round dunes possess as a peculiar feature an almost bare sandy zone shaped like a horseshoe. The upper boundary of the bare zone is formed by the storm-flood mark in a Koelerion-community, its lower boundary is formed by the upper limit of the highest community of the halosere: the Juncetum gerardii. The convex side of the horseshoe is exposed to the west. The horseshoes originate from the erosion by storm-floods from western directions. 
The investigations on the Boschplaat - comprised in this paper were performed on some of the "horseshoe" dunes unless stated otherwise. For further information about the locality of this survey the reader may be referred to: De Fouw (1963), Visser (1947), WESTHOFF (1947 and 1951).

\section{The vegetation}

Table 1 renders a brief survey of the plant communities between the levels of storm-flood and spring tide on the Boschplaat. It is composed of fifteen sample plot analyses made according to the method of BRAUN-BLANQUET $(1951,1932)$ in the summers of 1962 and 1963. The first five columns give an impression of the association: Centaurieto-Saginetum moniliformis Diemont, Sissingh et Westhoff, 1940. This plant community occurs just above the boundary line between the xerosere and the halosere: $154 \mathrm{~cm}+$ N.A.P. ("New. Amsterdam Level') ${ }^{1}$ ). On the horseshoe dunes vegetations of this type are found in the rather open horseshoe zone. This community consists of three groups of species. First there is a group of true dune plants mainly belonging to the alliance: Koelerion albescentis (Braun-Blanquet 1936) Weevers 1940. One of these dune plants is Festuca rubra ssp. rubra var. arenaria Fries, which is often the dominant species. The second group is composed of halophytes. These species often possess a reduced vitality on this level of the salt marsh, but they demonstrate the still existing influence of the salt factor.

Centaurium vulgare $\mathrm{Rafn}^{2}$ ) and Sagina nodosa var. moniliformis Meyer - in the middle group of species in Table 1 - are the faithful species of the Centaurio-Saginetum. Both species possess an optimal development in this zone on the Boschplaat. As pioneer plants they prefer an open, sandy and moist soil. Centaurium vulgare is oligohalobious according to FREIJSEN (1964). Sagina nodosa is salt-tolerant. The Centaurio-Saginetum is also met with in young primary dune valleys which are just being cut off from the sea. Most descriptions of the Centaurio-Saginetum originate from such sites e.g. WesthofF (1947) and also the original one: Diemont et al. (1940).

The other species of the third group in Table 1 belong to the related association: Sagineto maritimae-Cochlearietum danicae (Tx. 1937) Tüxen et Gillner 1957. This plant community occurs in the ecotone between the xerosere and the halosere. It is composed of annuals and biennials like Sagina maritima, Cochlearia danica and Parapholis strigosa. All the characteristic species of this community prefer a fluctuating water content and salinity of the soil. They establish themselves on open patches within plant communities of the Armerionalliance, which they cover as a 'carpet' (Teppich-Gesellschaft sensu

1) Data of elevation are based on a few measurements only.

2) The author prefers the name Centaurium vulgare Rafn to Centaurium littorale (Turner) Gilmour, which was used in a previous paper. The latter is also used in some modern Westeuropean floras. However the only correct name is Centaurium vulgare Rafn as is discussed by JoNKER (1950). 


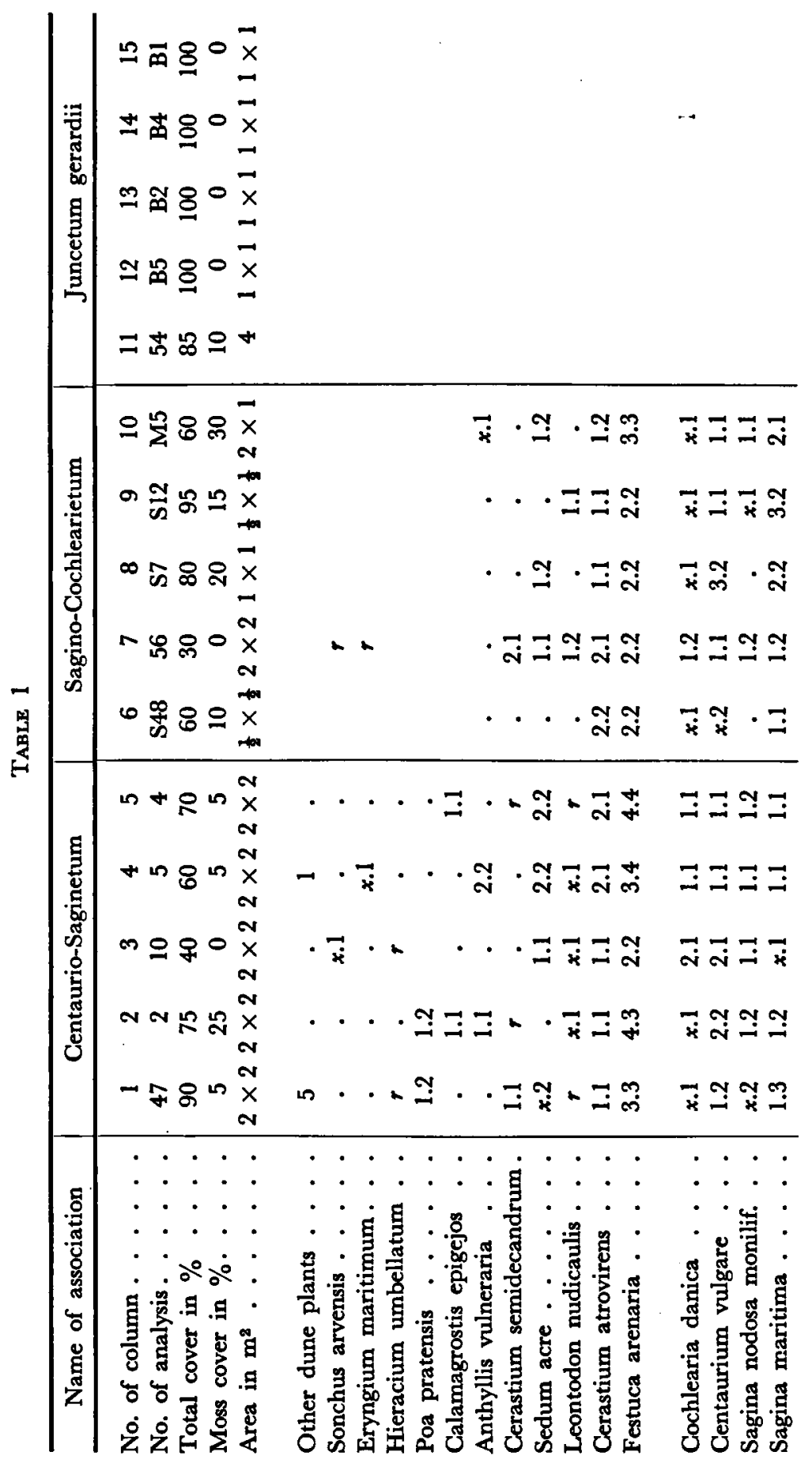




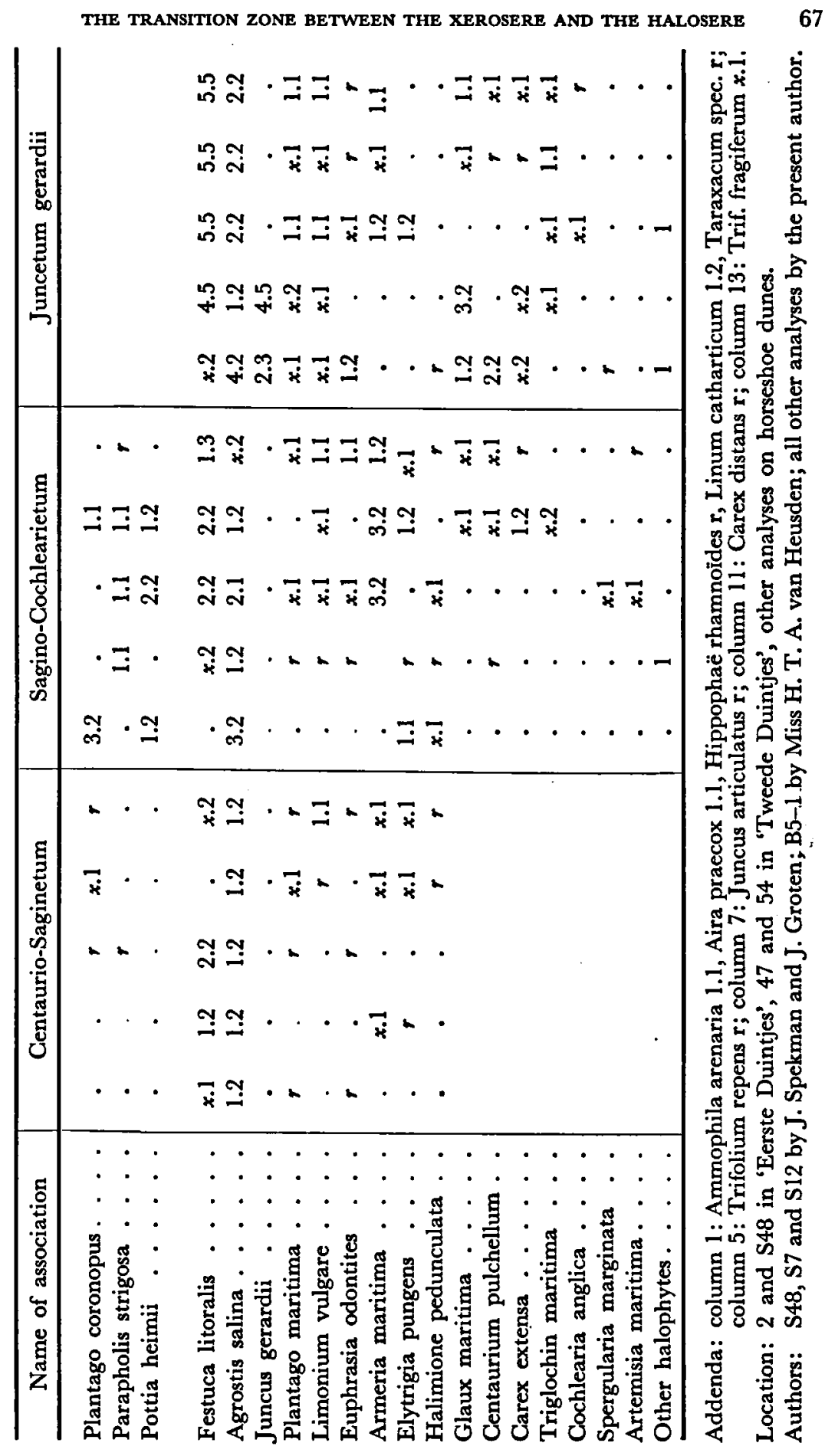


Tüxen). Many papers have been published on the Sagino-Cochlearietum in recent years: BeEFTINK (1965), TüxeN and WEsthofF (1963), Spekman and Groten (1963), Westhoff et al. (1962) and Tüxen (1957).

The relationship between the Centaurio-Saginetum and the SaginoCochlearietum is strong. It is difficult to make a sharp distinction between the two on the Boschplaat. In general it can be said, that Centaurium vulgare and Sagina nodosa prefer a somewhat drier and less saline soil than the species of the Sagino-Cochlearietum. This explains why Cochlearia danica - typical for the dry subassociation sedetosum of the Sagino-Cochlearietum possesses a high vitality in the CentaurioSaginetum. In view of the strong ecological similarity of the CentaurioSaginetum and the Sagino-Cochlearietum the characteristic species of these two communities were combined in Table 1 and discussed here together. A more detailed description of both communities on the Boschplaat and their mutual relations will be published in the future.

On the horseshoe dunes the open vegetations of the CentaurioSaginetum suddenly pass into the very closed sward of Festuca rubra $f$. litoralis Hackel. The last five columns of Table 1 give an impression of the plant community, in which this paramorph of Festuca rubra dominates. Apart from the most important species, Festuca litoralis, two other species can dominate, viz. Agrostis stolonifere subvar. salina Jansen et Wachter 1940 and Funcus gerardii (cf. VAN Heusden, 1963). The former occurs especially in the brackish slacks of the "Duintjes" (column 11) and the latter on more wet places (column 12). The old name for this community is: Armerieto-Festucetum (W. 1890) Braun-Blanquet et de Leeuw 1936. BeEfTINK (1965) uses the name: Funcetum gerardii Warming 1906. This author distinguishes three variants with dominance of respectively Festuca litoralis, Agrostis salina and Juncus gerardii.

These three variants were observed on the Boschplaat too as was already suggested. In the funcetum gerardii a number of other halophytes, mostly with a low abundance and vitality are found. Dune plants do not occur within it as a consequence of the high density of the vegetation and the soil properties. The lower limit of the Funcetum corresponds with the spring tide level $=127 \mathrm{~cm}+$ N.A.P.

The columns 5 to 10 represent the Sagino-Cochlearietum of the Boschplaat. The most essential features of this community were already described above. We can subjoin the following remarks. As in the case of the Centaurio-Saginetum there are the two opposite groups of dune plants and halophytes. Differing from the Centaurio-Saginetum the accent lies on the halophytes. The two paramorphs of Festuca rubra are in balance. The community is typified by the occurrence of Sagina maritima, Plantago coronopus, Parapholis strigosa and Pottia heimii, the vitality of Sagina maritima is better than in the CentaurioSaginetum, but on the other hand Centaurium vulgare and Sagina nodosa form much smaller plants in the Sagino-Cochlearietum. As is told above the Sagino-Cochlearietum develops on open spots of other vegetations. 
In our case these open spots lie in the funcetum gerardii. There they arise by erosion during gale-floods and also as a consequence of the combined influence of dryness and a high salt concentration on the original vegetation. Maybe flood marks play a part. The lower limit of the Sagino-Cochlearietum on the horseshoe dunes is about $137 \mathrm{~cm}+$ N.A.P.

\section{THE sOIL}

The soil surface in the funcetum gerardii is covered by a thick layer of dead organic material. Its decomposition takes much time. The upper layer of the mineral soil, about $5 \mathrm{~cm}$, contains $4 \%$ silt and clay.

The soil surface of the Sagino-Cochlearietum is coated with algae especially Cyanophyceae, among others Nostoc microscopicum. The substratum for these algae is formed by the silty top layer of the soil. The approximately $1 \mathrm{~cm}$ thick layer contains up to $6 \%$ silt and $3 \%$ organic material.

Contrary to the two just described soils, the soil of the CentaurioSaginetum is almost completely sandy. The amount of humus is negligible. Algae are present but barely visible. However, these few algae are responsible for the formation of a crust-hard soil surface during spells of dry weather. Both the algae and crystallized salts cement the sand grains together.

TABLE 2

\begin{tabular}{|c|c|c|c|c|c|c|}
\hline Association & \multicolumn{2}{|c|}{ Cent.-Sag. } & \multicolumn{2}{|c|}{ Sag.-Cochl. } & \multicolumn{2}{|c|}{ Junc. ger. } \\
\hline soil layer in $\mathrm{cm}$. & $0-1$ & $1-20$ & $0-1$ & $1-20$ & $0-5$ & $5-20$ \\
\hline $\begin{array}{l}\max . \mathrm{H}_{2} \mathrm{O}-\% . \\
\min . \\
\max . \\
\min \end{array}$ & $\begin{array}{c}10.8 \\
0.2 \\
(1.20) \\
0.02\end{array}$ & $\begin{array}{c}16.0 \\
2.3 \\
0.10 \\
0.02\end{array}$ & $\begin{array}{c}31.9 \\
0.7 \\
(0.59) \\
0.01\end{array}$ & $\begin{array}{l}18.6 \\
3.6 \\
0.09 \\
0.01\end{array}$ & $\begin{array}{c}213.9 \\
53.9 \\
0.61 \\
0.02\end{array}$ & $\begin{array}{l}30.4 \\
15.1 \\
0.44 \\
0.05\end{array}$ \\
\hline
\end{tabular}

All figures are based on twelve fortnightly samplings in $1964, \mathrm{H}_{2} \mathrm{O}$-content in $\%$ of dry soil and $\mathrm{Cl}^{\prime}$-content as concentration of soil moisture. For method and for comparison, see FrEIJSEN (1964).

Table 2 gives a survey of the water relations and the salinity in the communities studied. From left to right in Table 2 the water content and the salinity increase. The superficial layers of the SaginoCochlearietum and the funcetum gerardii can contain a high amount of water. The layer of $5-20 \mathrm{~cm}$ in the latter association is permanently saturated with water because of a high phreatic level. The minimum water content in the Centaurio-Saginetum and the Sagino-Cochlearietum can be very low. Especially the surface of the soil in these associations can desiccate strongly.

The Cl'-concentrations in the Centaurio-Saginetum and the SaginoCochlearietum are almost the same, but the absolute amount of Cl-ions (= potential salinity sensu AdRIANI in: Westhoff et al., 1962) is higher in the Sagino-Cochlearietum. This absolute amount is higher, 
but also the moisture content in the latter is higher as well, resulting in a $\mathrm{Cl}^{\prime}$-concentration, which is the same as in the Centaurio-Saginetum.

The situation in the funcetum gerardii is quite different. A higher degree of salinity goes with a permanently wet soil. The funcetum gerardii is a true salt community. The two maximum $\mathrm{Cl}^{\prime}$ figures of the topmost layers of the Centaurio-Saginetum and Sagino-Cochlearietum are placed between brackets. It is questionable, whether such high values really exist. According to BeEFTink (1965) crystallization must happen under these circumstances.

Other soil factors differ only slightly and probably do not determine the boundaries of the three associations. The only remarkable feature is a somewhat greater richness of nutrients in the $0-4 \mathrm{~cm}$ layer of the Funcetum gerardii.

\section{The FIELd Plots}

\section{Introduction}

The previous parts render a short survey of the most important plant communities on the Boschplaat between the levels of stormflood and spring tide. Secondly the critical soil factors in these habitats are summarized. In order to get an idea about the origin of this ecotone, five field plots were laid out, transverse to the zonation. By digging up the soil and removing the original vegetation and a part of the grass roots, bare sandy plots were prepared. The cover of algae and silt disappeared and so the soil material was about identical throughout the fields. (In two other field plots - not mentioned here - the lower part was filled with sand from high on the dune slope. The results of these two fields correspond with the following remarks and conclusions.) Only the water relations must have been different from the starting point as a consequence of the gradient in the water-table. This was also the case with the $\mathrm{Cl}^{\prime}$-concentration, which depends upon the soil moisture.

Table 3 renders the details about number, data of laving-out and last inspection and size of the five field plots. The plots 1,2 and 3 were laid out on west slopes of horseshoe dunes with distinct zones; plots 4 and 5 were situated in respectively the 'Eerste Duintjes' and 'Tweede Duintjes'. As was told in part 1, the Funcetum of the 'Duintjes' is characterized by a low salinity and the dominance of Agrostis stolonifera salina. This difference appeared in the development of field plots 4 and 5 .

To make sure the establishment of Centaurium vulgare in the field plots, for which phenomenon much interest existed (see part 4), all field plots, except no 5, were sown with seed of Centaurium vulgare, collected on the Boschplaat.

\section{Discussion of Table 3}

Table 3 renders a survey of all species which established themselves on the field plots within the period between the laying-out 
and the last inspection. As far as possible they are placed in the same order as in Table 1. For this investigation a period of one year was chosen so that plants normally germinating in spring as well as plants germinating in autumn should have at least one opportunity to germinate. In Table 3 the presence of a species after one year is designated by the symbol + ; the absence by the symbol - . Species only one time occurring on all fields together are joined as 'other dune plants' and 'other halophytes'.

TABLE 3

\begin{tabular}{|c|c|c|c|c|c|}
\hline $\begin{array}{l}\text { No. of field plot. } \\
\text { Date of laying-out } \\
\text { Date of last inspection } \\
\text { Size in } \mathbf{m}^{2}\end{array}$ & $\begin{array}{l}1 \\
\text { Apr. } 1964 \\
\text { Jun. } 1965 \\
10 \times 2,5 \\
\end{array}$ & \begin{tabular}{|c|}
\multicolumn{2}{|c}{2} \\
Nov. 1962 \\
Oct. 1963 \\
$6 \times 1,25$ \\
\end{tabular} & \begin{tabular}{|c|} 
\\
3 \\
Nov. 1962 \\
Oct. 1963 \\
$6 \times 1,25$ \\
\end{tabular} & \begin{tabular}{|c|}
4 \\
Aug. 1962 \\
Jul. 1963 \\
$3 \times 2$ \\
\end{tabular} & $\begin{array}{c}5 \\
\text { Aug. } 1962 \\
\text { Oct. } 1963 \\
3 \times 2 \\
\end{array}$ \\
\hline \multicolumn{6}{|l|}{ In dry half of field plot: } \\
\hline $\begin{array}{l}\text { Other dune plants . . } \\
\text { Elytrigia juncea }\end{array}$ & $\begin{array}{l}3 \\
+\end{array}$ & $\begin{array}{l}0 \\
+\end{array}$ & $\begin{array}{l}0 \\
+\end{array}$ & 0 & 2 \\
\hline Trifolium repens . : & + & + & + & - & 一 \\
\hline Lotus corn. ssp. corniculatus & + & - & - & + & - \\
\hline Sonchus arvensis. . . . . . & + & + & + & - & + \\
\hline Poa pratensis $\cdot \dot{C}^{\circ} \cdot \dot{*}^{-}$ & \pm & 二 & 二 & \pm & $\overline{1}$ \\
\hline 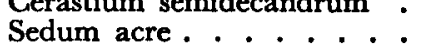 & $\bar{t}$ & $\bar{t}$ & $\bar{t}$ & + & $\dot{t}$ \\
\hline Leontodon nudicaulis . . . & + & - & + & + & + \\
\hline Cerastium atrovirens : : - & + & + & + & + & + \\
\hline $\begin{array}{l}\text { Festuca rubra v. arenaria } \\
\text { Cochlearia danica. . . }\end{array}$ & + & + & + & + & + \\
\hline \multicolumn{6}{|l|}{ In wet half of field plot: } \\
\hline Centaurium vulgare .... & + & + & + & + & + \\
\hline Sagina nodosa v. moniliform. & + & + & + & + & + \\
\hline Sagina maritima. . . . . . & + & + & + & + & 一 \\
\hline Plantago coronopus $\cdot \cdot \cdot \cdot$ & + & + & - & - & - \\
\hline Festuca rubra f. litoralis . . & + & + & + & + & - \\
\hline Agrostis stolon. v. salina . . & $t$ & + & + & $t$ & + \\
\hline Limonium vulgare . . . . . & + & + & + & - & - \\
\hline Euphrasia odontites . . . & + & + & - & - & 一 \\
\hline Armeria maritima ; . . . & + & $\div$ & + & + & - \\
\hline Halimione pedunculata . . . & + & + & + & $一$ & 一 \\
\hline Glaux maritima $\cdot . \cdots$ & + & + & + & + & 一 \\
\hline Centaurium pulchellum . . & + & + & + & - & - \\
\hline Cochlearia anglica . . . . & + & + & - & + & 一 \\
\hline Potentilla anserina . . . . . & + & $\overline{3}$ & $\overline{1}$ & + & $\overline{0}$ \\
\hline Other halophytes $\cdot \cdots$ & 1 & 3 & 1 & $\mathbf{0}$ & 0 \\
\hline \multicolumn{6}{|l|}{ Throughout the field plot: } \\
\hline Plantago maritima. . . & + & + & + & - & - \\
\hline Elytrigia pungens . . . & + & $\dot{t}$ & + & 一 & - \\
\hline Artemisia maritima . . & + & + & + & - & - \\
\hline Atriplex hastata . . . . & + & - & - & 一 & - \\
\hline Total number of plants. & 32 & 25 & 22 & 17 & 12 \\
\hline
\end{tabular}


The species in Table 3 are divided into three groups:

a. the first group consisting of xerophile species occurring only or especially on the upper dry half of the field plots,

b. a second group of relatively hydrophilous species mostly occurring on the wet lower half of the field plots,

c. a third group of a few species which occurred throughout the field plots with similar abundance.

After a year the most important Koelerion-species of Table 1 had established themselves on the upper half of the field plots. In many rcspects the original composition and structure of the vegetation was restored. A conspicuous difference was formed by Sonchus arvensis and Elytrigia juncea. Both psammophile plants were apparently favoured by the loose sandy surface in the upper part of the plots. Interesting was the preference of Cochlearia danica to the dry half of the plots. In this way the mentioned xerophile character of this Sagino-Cochlearietum species appeared.

The species in the first group of Table 3 did almost not establish themselves in the wet half of the plots which corresponded with the funcetum gerardii. This was unexpected as some disadvantageous features were absent, e.g.: a high density of the vegetation, a thick layer of litter, and a higher silt content. The conclusion must be that the lower limit of these species on the Boschplaat is determined by the water and salt content of the soil. These must be the main reasons that they do no occur in the funcetum gerardii and that they possess a lower vitality in the Sagino-Cochlearietum. Indeed they are oligohygrobious and oligohalobious plants sensu IVERSEN (1936).

Among the species of the wet lower halfs of the field plots there are many halophytes mentioned as such in Table 1 . With regard to the factors water and salt these species behaved oppositely to those of the Koelerion. Shortness of water and salt were the causes that the true halophytes of the funcetum gerardii did not reach a high abundance or dominance on the level of the Centaurio-Saginetum. The species of the wet halfs of the plots are mesohygrobious and mesohalobious (IVERSEN, 1936). The number of these species is much lower in the field plots 4 and 5 . In field plot 5 Agrostis salina is the only 'halophyte'. The more fresh character of the environment - the slacks of the 'Duintjes' - must be the cause.

Four species of the two associations Centaurio-Saginetum and SaginoCochlearietum exhibit another trend: Centaurium vulgare, Sagina nodosa var. moniliformis, Sagina maritima and Plantago coronopus. Their area in the field plots was restricted to the lower half contrary to the normal situation. The upper boundary for the plants of Centaurium vulgare and Sagina nodosa was below the boundary line between the CentaurioSaginetum and the funcetum gerardii in the surrounding vegetation. This upper boundary - normally occurring on the level of the stormflood mark - was shifted downwards. On the field plots the CentaurioSaginetum did not occur, but coincided with the 'community' of Sagina maritima. 
The following explanation is possible. Centaurium and the other species prefer rather wet soils especially during germination. However the soil surface in the upper halfs of the field plots was dry and loose. Furthermore favourable microhabitats were nearly absent as a consequence of the particular preparation of the field plots. Recently HARPER et al. (1965) have shown the importance of the 'microtopography' for germination. In the undisturbed Centaurio-Saginetum - on the same elevation as the dry halfs of the field plots - enough microhabitats occur. In the wet halfs of the plots germination happened especially below drift material, in the shadow of small tussocks etc. The microrelief appeared to be important here too.

After some time the species of the Sagino-Cochlearietum seemed to be superseded by the dominant growth of grasses, especially Agrostis stolonifera salina; and Festuca rubra litoralis. This development was prohibited by removing the stolons of the grasses. Also under natural conditions the Sagino-Cochlearietum can be succeeded by the Funcetum gerardii, in which succession the constructive capacities of the grasses are of major value. The grasses increase the density of the vegetation. This process is favourable for the sedimentation of silt, but unfavourable for the occurrence of the pioneer plants of the Sagino-Cochlearietum. Thus a Funcetum-community develops. Some of the species of the Sagino-Cochlearietum can find a refuge on a higher level, namely in the Centaurio-Saginetum e.g. Sagina nodosa and Plantago coronopus.

In the third group of Table 3 four plants occur, which possessed the same abundance throughout the field plots 1,2 and 3 . Their diaspores were conveyed in the tidal drift. The plants themselves profited of the presence of the organic material. Especially Elytrigia pungens and Atriplex hastata are found on places, where tidal drift is deposited on the salt marsh. These four species were not found on the field plots 4 and 5 in the slacks of the 'Duintjes'. These dunes are inundated some times a year, but the quantity of deposited tidal drift is extremely low. The absence of these four. species mentioned and of many halophytes caused the low total number of plants on these fields.

\section{Centaurium vulgare Rafi}

During the investigations on the field plots special attention was given to Centaurium vulgare Rafn. This species has some paramorphs described by JONKER (1950) and also by other authors. On the Boschplaat the typical Centaurium vulgare occurs. Normal adult specimens of this paramorph are characterized by a number of branched erect 'stems, narrow somewhat succulent leaves and purple-rose flowers. Their rosettes die off after the winter.

It was the purpose to get information about the life-history and the distribution of this paramorph of Centaurium in the zone between the levels of storm-Hood and spring tide. In order to be sure that Centaurium iulgare should occur, seeds of this species were sown on the field plots, as well as on two control plots in the natural vegetation 
alongside the plots 2 and 3. As was mentioned in a previous section, Centaurium vulgare established itself only in the lower part of the field plots, always below the boundary line between the xerosere and the halosere.

\section{The life-cycle}

About the life-cycle of Centaurium oulgare the following can be said. On 20 May 1963, not a single seedling was found on the field plots 2 to 5 . In the surrounding vegetation the first seedlings were already found in April. The cause of this delay of germination has not been cleared yet. During their first summer the seedlings developed in rosettes. The plants hibernated as rosettes and after exactly one year they formed stems. They flowered in July and August of the second summer. After the leaves and stems had turned yellow the plants formed seeds. These plants behaved as true biennials as is the normal way for Centaurium vulgare.

\section{The distribution pattern in field plot 2}

The distribution of Centaurium vulgare in the field plots can be explained in a description of the occurrence of Centaurium vulgare in field plot number 2 . In this respect field plot 2 was representative for all plots.

On 31 July 1964 - in the flowering-time of Centaurium vulgare size and density of the specimens of Centaurium vulgare on plot 2 were measured. Table 4 contains the results of this investigation. First there is a longitudinal profile on scale of the lower half of field plot 2 , which corresponds with the Funcetum gerardii. As mentioned above Centaurium vulgare occurred only in this part of the field plot. This half was subdivided in five subplots of $35 \times 135 \mathrm{~cm}^{2}$. In each subplot the following properties of Centaurium vulgare were determined:

a. the total number of plants

b. the maximum length of the stems

c. the average number of flowers per plant

d. the average number of stems per plant

e. the average dry weight in $g$ per plant.

No plant of Centaurium vulgare occurred in subplot 1. The first specimens were found in subplot $2,10 \mathrm{~cm}$ below the boundary line between the Centaurio-Saginetum and the funcetum. The subplots 3 and 4 possessed the highest density of specimens of Centaurium vulgare. Above and below these two patches the density decreased. Going down the slope the length of the stems decreased. The decreasing size of the plants on the slope was more clearly shown by the diminishing number of flowers from 70 to 8 per plant in the subplots 2 to 5 . Normally each flower produces a fruit. From other investigations 
it appeared that big plants use to produce more seeds per fruit. So it is allowed to conclude, that the seed production in the highest subplots was much higher than below, at least per plant.

The same tendency - decreasing vitality of the plants in the lower subplots - appears from the data about the average number of stems and the average dry weight.

It can be supposed that the lower half of field plot $2-$ in which Centaurium vulgare growed - possessed a high homogeneity. At the start of the experiment the environment was the same throughout the field plot. An exception was formed by the soil moisture which increased going down the slope. Hence the changing water content of the soil must be the cause of the distribution pattern of Centaurium vulgare.

Three zones could be discerned in the "Centaurietum" of field plot 2:

1. upper zone with few big plants of Centaurium vulgare $=$ subplot 2

2. middle zone with highest density and rather small plants = subplot 3 and 4

3. lower zone with few and very small plants $=$ subplot 5 .

\section{Discussion}

The relation between the distribution pattern of Centaurium vulgare and the soil moisture can be explained as follows. On the top of a sandy dune slope the soil water becomes the limiting factor for Centaurium vulgare. For germination the water content only suffices on a few places e.g. pores in the soil surface or shadowing tussocks etc. (see above). The density of seedlings is always low. These dispersed seedlings exhibit a rapid growth. Their roots become soon long enough to reach a depth with sufficient capillary water.

Somewhat lower on the same dune slope the surface is wetted by capillary rise from the water-table during spring. Here the water factor is no more limiting the germination. That's why the number of seedlings of Centaurium vulgare is much higher. The density of the rosettes and later the adult plants, which develop from the seedlings, is so high that they exhibit a negative influence on each other. This phenomenon must be an example of competition within one species. We can say that density is inversely proportional to size and production of the individual plants of Centaurium vulgare.

The competition of Centaurium vulgare resembles that observed by Bleasdale (1960) and Harper (1960) in their studies with weeds. The amounts of water and light can not be in short supply. As we have seen, the soil moisture is high in the middle part of the Centauriumzone. Also in dense Centaurium-populations the amount of light is always sufficient. Their density and height is not high enough to hinder the penetration of the light. Thus a shortness of nutrients must be the limiting factor. The rightness of this conclusion was proved by an experiment with fertilizers. The size of the Centauriumplants in dense populations increased after supply with fertilizer. 
On the lower edge of dune slopes the permanently high content of soil moisture becomes increasingly unfavourable for Centaurium vulgare. The presence of a coating of algae - as a consequence of the high humidity - may be disadvantageous too. The number of seedlings is low and becomes still lower by mortality. In spite of the wide interspaces between the individual plants, which makes competition for nutrients very improbable, they grow slowly and the adult plants attain only a small size.

The different size and density of Centaurium vulgare on high and low levels of dune slopes use to occur in natural vegetations too. Centaurium vulgare possesses big specimens and a low density in the Centaurio-Saginetum of the Boschplaat. On the other hand, in the Sagino-Cochlearietum we meet many rather small specimens. The columns 2 and 3 in Table 4 symbolize these two situations in the behaviour of Centaurium vulgare.

\section{TABLE 4}

Size and density of Centaurium vulgare in the lower half of field plot 2

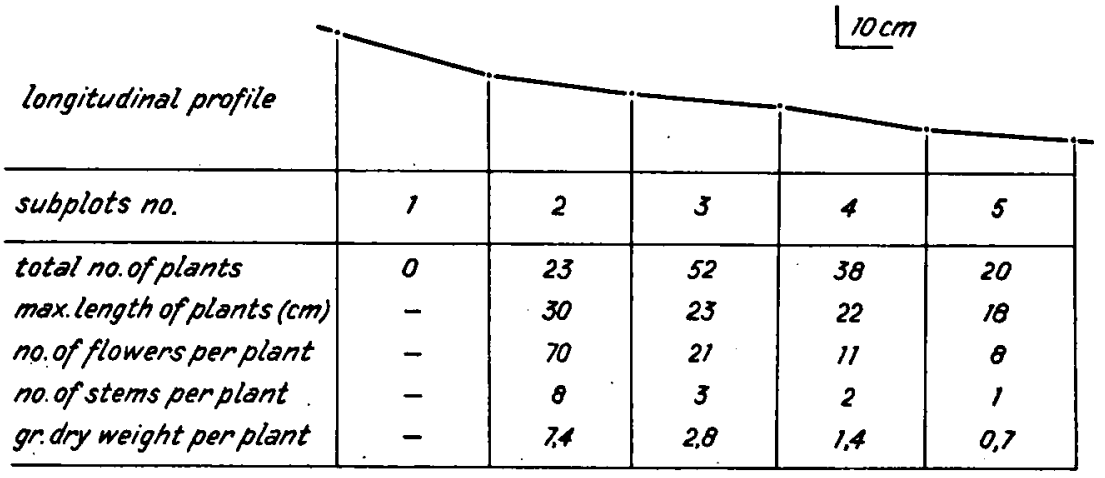

Finally the following remarks can be made with reference to the field plots. First it is peculiar that there were almost no seedlings of Centaurium vulgare on them in the second season after their layingout. It can be concluded that there was just a very low amount of viable seeds. Either the original seed had germinated, or it had lost its germinative power. New seed was not conveyed from the neighbourhood, although there were enough seed producing plants. The conclusion must be that, as a rule, the seeds of Centaurium vulgare are dispersed over small distances only. This conclusion is in accordance with observations in a very young dune region of Terschelling: the 'Noordvaarder'. There the area of Centaurium vulgare does not extend to its possible limits. The expansion of Centaurium vulgare is slower than the development of new habitats. That is: the dispersal of Centaurium vulgare is a limiting factor for the rate of extension of its range.

In spite of sowing the density and distribution of Centaurium vulgare in the two control plots was quite the same as under natural cir- 
cumstances. No plants occurred in the Funcetum gerardii of these plots. In this respect the behaviour of Centaurium vulgare was not influenced by sowing, just as was expected.

The biomass of Centaurium vulgare on field plot 2 (see Table 4) was significantly higher than on an area of the same size in a natural habitat. Also other plants attained a larger size. Without doubt this phenomenon is a result of a higher amount of easily available nutrients, because the soil had been dug up.

\section{ACKNOWLEDGEMENTS}

The author wishes to express his gratitude to the 'Foundation for Scientific Dune Research' (S.W.D.; president Prof. Dr. J. Lanjouw) and the 'Netherlands Organisation for the Advancement of Pure Research' (Z.W.O.), which enabled him to carry out the investigation described. Thanks are also due to Dr. Ph. Stoutjesdijk who kindly corrected the English text.

\section{REFERENCES}

BeEfrink, W. G. 1965. De zoutvegetatie van ZW-Nederland beschouwd in Europees verband. Wageningen.

Bleasdale, J. K. A. 1960. Studies on plant competition. In: The biology of weeds. lst Symposium Brit. Ec. Soc.: 133, Oxford.

Braun-Blanguet, J. 1932. Plant Sociology. New York-London. 1951. Pflanzensoziologie. Wien.

Diemont, H. W., G. Sissingh and V. Westhofr. 1940. Het Dwergbiezenverbond (Nanocyperion flavescentis) in Nederland. Ned. Kruidk. Arch. 50: 215.

Fouw, J. E. L. DE. 1963. Een onderzoek naar de verspreiding en patroonvorming van een aantal plantensoorten op de duintjes van de Boschplaat van Terschelling. Utrecht, Botanical Museum and Herbarium (mimeographed).

Freijsen, A. H. J. 1964. Remarks on the halophyte Centaurium littorale. Proc. Koninkl. Ned. Akad. Wetensch., Series C, 67: 208.

Harper, J. L. 1960. Factors controlling plant numbers. In: The biology of weeds. 1st Symposium Brit. Ec. Soc.: 119, Oxford.

J. T. Williams and G. R. Sagar. 1965. The behaviour of seeds in soil. I. The heterogeneity of soil surfaces and its role in determining the establishment of plants from seed. J. Ecol. 53: 273.

Heusden, H. T. A. van. 1963. Morfologisch en vegetatiekundig onderzoek naar de infraspecifieke eenheden van Festuca rubra L. Utrecht, Botanical Museum and Herbarium (mimeographed).

Jonker, F. P. 1950. Revisie van de Nederlandse Gentianaceae. I. Centaurium Hill. Ned. Kruidk. Arch. 57: 169.

Iversen, J. 1936. Biologische Pflanzentypen als Hilfsmittel in der Vegetationsforschung. Medd. fra Skalling-Laboratoriet 4. Kopenhagen.

Spekman, J. and J. Groten. 1963. Enkele aspecten van het Saginetum maritimae op de Beer en de Boschplaat. Utrecht, Botanical Museum and Herbarium (mimeographed).

Tüxen, R. et al. 1957. Die Pflanzengesellschaften des Aussendeichslandes von Neuwerk. Mitt. Flor.-soz. Arbeitsgem. N.F. 6/7: 205.

and V. WESTHOFF. 1963. Saginetea maritimae, eine Gesellschaftsgruppe im wechselhalinen Grenzbereich der europäischen Meeresküsten. Mitt. Flor.-soz. Arbeitsgem. N.F. 10: 116.

Visser, J. C. 1947. Stuifdijken op Vlieland en Terschelling. Tijdschrift Kon. Ned. Aardr. Gen., Tweede Reeks, 64: 31. 
WEsthofF, V. 1947. The vegetation of dunes and salt marshes on the Dutch Islands of Terschelling, Vlieland and Texel. 's-Gravenhage.

1951. De Boschplaat op Terschelling. Natuur en Landschap 5: 3.

C. G. van Leeuwen and M. J. Adriani. 1962. Enkele aspecten van vegetatie en bodem der duinen van Goeree, in het bijzonder de contactgordels tussen zoet en zout milieu. Wet. Gen. Goeree-Overflakkee, Jaarboek 1961: 47. 